\title{
Effect of Artificial Ageing on Adhesive Bonds from Heat Treated Spruce
}

\section{Utjecaj umjetnog starenja na lijepljeni spoj toplinski modificirane smrekovine}

\author{
Original scientific paper • Izvorni znanstveni rad \\ Received-prispjelo: 20. 11. 2020. \\ Accepted-prihvaćeno: 26. 5. 2021. \\ UDK: $630 * 824.322 ; 630 * 824.323 ; 630 * 824.52$ \\ https://doi.org/10.5552/drvind.2021.2044
}

\begin{abstract}
The influence of artificial ageing on bonded heat-treated spruce lamellas was investigated. Heattreated spruce lamellas with different degrees of thermal modification were bonded with PVAc and MUF and then exposed to 500 artificial weathering cycles, combined with rain, UV and IR radiation. The colour change of the exposed surface, weight change, delamination of the bonded joints and adhesive bond strength were measured. Artificial weathering caused cracking and delamination of the bonded joints and reduced the bond strength of both adhesives. The results show that delamination was higher for PVAc adhesive than MUF, but increased for both adhesives with the temperature of heat treatment of wood. The shear strength of bonds on the exposed side of the samples after the artificial weathering was lower than the average strength of the whole sample.
\end{abstract}

Keywords: heat treated spruce; adhesive bond; artificial ageing; shear strength; delamination; colour change

SAŽETAK • U radu je istražen utjecaj umjetnog starenja na lijepljene lamele toplinski modificirane smrekovine. Lamele toplinski modificirane smrekovine različitih stupnjeva toplinske modifikacije lijepljene su PVAc i MUF ljepilom, a zatim su tijekom 500 ciklusa izložene vremenskim utjecajima u kombinaciji kiše te UV $i$ IR zračenja. Mjerena je promjena boje izložene površine, promjena mase te delaminacija i čvrstoća lijepljenog spoja. Umjetno izlaganje vremenskim utjecajima uzrokovalo je pucanje $i$ delaminaciju lijepljenih spojeva te smanjenje čvrstoće spoja lijepljenog obama ljepilima. Rezultati pokazuju da je delaminacija bila veća na slojevima s PVAc ljepilom nego na slojevima lijepljenim MUF ljepilom, ali je povećana na slojevima s oba ljepila, uz povećanje temperature toplinske modifikacije drva. Nakon umjetnog izlaganja vremenskim utjecajima smična je čvrstoća lijepljenog spoja na izloženoj strani uzoraka bila niža od prosječne čvrstoće cijelog uzorka.

Ključne riječi: toplinski modificirana smrekovina; lijepljeni spoj; umjetno starenje; smična čvrstoća; delaminacija; promjena boje

\section{INTRODUCTION 1. UVOD}

Thermal modification of wood can influence the gluing process with adhesives (Kariz, 2011) and reduce the performance of glued joints (Sernek et al., 2008). The shear strength of glued joints is usually re- duced due to the lower strength of the modified wood (Esteves and Pereira, 2009) and the lower adhesion to the modified wood surface. Studies had shown that heat treated (HT) wood can be adequately bonded to most industrial wood adhesives with some modifications of the bonding process (longer pressing time, lower wood moisture content) and/or adhesive (higher

${ }^{1}$ Authors are researchers at University of Ljubljana, Biotechnical Faculty, Department of Wood Science and Technology, Ljubljana, Slovenia. 
solids content) (Militz, 2002; Mayes and Oksanen, 2003). What is less known is how the bonds in heattreated wood change over time due to modified wood properties.

The ability of a joint to maintain satisfactory long-term behaviour, often in severe environments, is an important prerequisite for an adhesive joint, as the joint should be able to bear the intended loads for the intended life of the joint (Custódio et al., 2009). Over the years, the strength of the joints may decrease. Water and thus increased moisture content (MC) of the wood as well as the temperature lead to a reduction of the mechanical properties of the joined part (wood) (Green et al., 1999) and of the adhesive (Vick, 1999) as well as of the bonded joint (Blanchet et al., 2003).

Factors that influence the durability of structural adhesive joints can be divided into three categories: environment (temperature, humidity, solar radiation), materials (the joined part, adhesive and intermediate phase between the two) and stresses (stresses to which the joint is exposed during or after exposure to the operating environment and which affect both durability and residual strength) (Custódio et al., 2009, Follrich et al., 2011). In general, the durability of wood and wood products in dry conditions is good, i.e. with a (MC) below $15 \%$.

Chemical degradation of the adhesive line in the form of hydrolysis of the adhesive can occur through increased temperatures (e.g. heat or energy such as ultraviolet rays) in combination with moisture. These processes can also be influenced by acidic or alkaline environments. The resistance to hydrolysis depends on the type of adhesive: urea-formaldehyde (UF) adhesives are less resistant to hydrolysis than melamineurea-formaldehyde (MUF) or phenolresorcinol-formaldehyde adhesives (PRF) (Marra, 1992).

Climate changes increase the hygroscopic exchange, which increases the shrinkage and swelling of wood. Alternating shrinkage and swelling leads to breakage of adhesive bonds and causes breaks in the bond or in the wood, but different adhesives react differently to artificial ageing with standard changing climate conditions (hot/cold, low/high RH): PUR adhesive can retain most of the initial strength, followed by MUF/UF adhesive and others (EPI, MUF, PRF) (Follrich et al., 2011). The PVA bond strength gradually decreased due to ageing processes (Blanchet et al., 2003). In addition, during swelling or shrinking, the induced stresses in the bond line and in the interface between two materials can be reduced by the creep behaviour of the adhesive used (Follrich et al., 2011).

The methods used to assess the durability of wood-based materials include long-term and shortterm tests. Long-term assessments, such as outdoor exposure tests, have many disadvantages, such as being time-consuming and difficult to perform and are related to the test site. Short-term assessments evaluate changes in mechanical properties after accelerated ageing treatments, such as immersion in water, cooking, steaming, freezing or drying. Such accelerated ageing tests are artificial, but in recent decades many attempts have been made to correlate deterioration due to outdoor ageing with accelerated ageing in the laboratory (Kojima and Suzuki, 2011).

Most of the research on the ageing of adhesive bonds carried out so far has attempted to simulate the effect of ageing of adhesive bonds by using standard procedures that include different ageing cycles, usually combining cycles with changing climatic conditions such as $\left(50{ }^{\circ} \mathrm{C} / 95 \%\right.$ relative humidity $(\mathrm{RH}),-20{ }^{\circ} \mathrm{C} /$ $65-70 \% \mathrm{RH}$ and $75^{\circ} \mathrm{C} / 15 \% \mathrm{RH}$ ) or with soaking in cold/boiling water, soaking in water under vacuum or pressure conditions, air drying at high temperature (70$\left.100{ }^{\circ} \mathrm{C}\right)$ (Kojima and Suzuki, 2011).

The influence of the ageing process on the bonds is evaluated by measuring the shear strength of the bond, the internal bond strength or by measuring the delamination of the bond. This could predict the change in bond strength due to differences in temperature and moisture content of the wood, which are likely to be the main effects on the shear strength of the bond. On the other hand, these methods eliminate the influence of sunlight and rain on the bonded surfaces, which could be important for outdoor furniture or doors/windows.

The aim of this study was to measure the effect of artificial ageing on glued joints made of heat-treated spruce wood, which was produced with different adhesives. Normally the ageing of wood joints is done by standard methods, including soaking in cold or boiling water, freezing, but we wanted to use the ageing method for surface coating to see what effect UV and IR radiation and rain have on glued joints.

\section{MATERIALS AND METHODS} 2. MATERIJALI I METODE

\subsection{Heat treatment of wood and bonding}

2.1. Toplinska modifikacija i lijepljenje

The spruce wood lamellae (Picea abies Karst) were heat treated at five different temperatures: 150, $170,190,210,230{ }^{\circ} \mathrm{C}$ using the method of heat treatment with initial vacuum phase (Rep et al. 2004). Modified lamellas were then conditioned in standard climate $\left(T=20^{\circ} \mathrm{C}, R H=65 \%\right)$ to achieve an equilibrium moisture $(M C)$ before bonding with adhesives. Untreated samples were also prepared, conditioned and bonded in the same conditions to serve as control.

Two cold-curing adhesives with higher water resistance were used: PVAc Rakol GXL 4, class D4, (H. B. Fuller) and MUF adhesive, (Casco adhesives AB). The lamellas were planed prior to bonding to ensure an even and fresh surface. The adhesive application rate was 180 $\mathrm{g} / \mathrm{m}^{2}$. Bonding was performed in a press at room temperature and a pressure of $1 \mathrm{~N} / \mathrm{mm}^{2}$. The pressing time of 60 minutes for PVAc and 3 hours for MUF adhesive was determined according to the manufacturer's recommendations (30 min for PVAc and $2 \mathrm{~h}$ for MUF) and extended due to the expected slower bonding of modified wood (Kariz et al., 2013). The glued lamellas were then conditioned in standard climate for a few months and then samples were sawn measuring $90 \mathrm{~mm} \times 34 \mathrm{~mm} \times$ $40 \mathrm{~mm}$, each sample containing two adhesive joints 

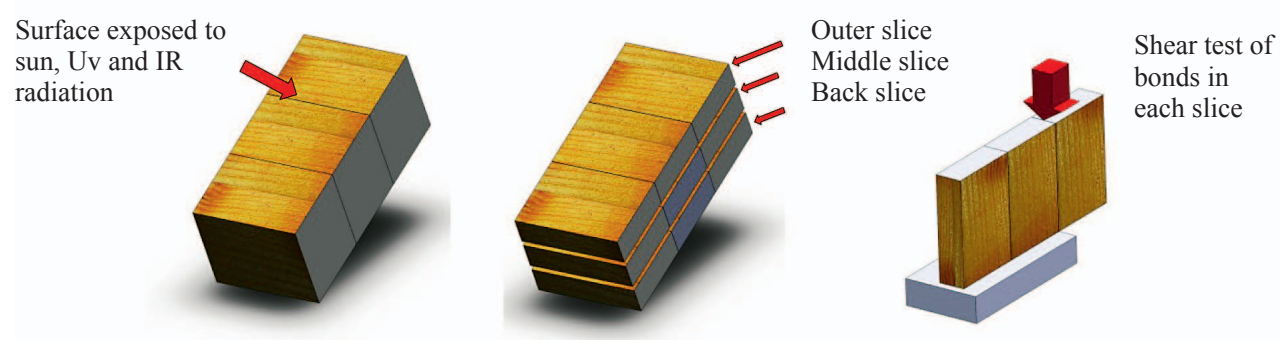

Figure 1 Left: position of specimens during artificial ageing cycles; middle: slicing specimens for bond shear testing; right: shear test of aged bonds

Slika 1. Lijevo: položaj uzoraka tijekom ciklusa umjetnog starenja; sredina: piljenje uzoraka za ispitivanje smične čvrstoće; desno: ispitivanje smične čvrstoće izloženog uzorka

(Figure 1 left). The cross sections were coated with twocomponent epoxy paint to prevent higher water absorption by these surfaces.

\subsection{Artificial ageing}

2.2. Umjetno starenje

The artificial ageing method was similar to the method used to test wood coatings for artificial weathering using fluorescent UV lamps, IR heating and water. The samples were exposed to artificial weathering in a special test chamber with water spray, UV and IR lamps. The duration of irradiation of IR was adjusted to reach $60{ }^{\circ} \mathrm{C}$ on white surfaces of the samples. The artificial weathering cycle lasted 1 hour and included 22 minutes of rain, 9 minutes of conditioning, 27 minutes of UV and IR irradiation and 2 minutes of conditioning. Every 100 cycles during the test, the samples were weighed, checked for cracks in the bond line and rotated in the chamber to eliminate the effect of possible uneven wetting and UV/IR irradiation. A total of 500 artificial weathering cycles were performed.

\subsection{Colour measurement}

2.3. Mjerenje boje

Colour change is not directly connected with bond strength change, but visually shows the severity of the ageing process and was thus measured to evaluate the possible correlation between surface colour change and bond strengths decrease. The colour of the samples was measured before and after the artificial ageing process. The samples were always conditioned in standard climate before the measurement to establish equilibrium $M C$. The colour of the surface was measured with the spectrophotometer SP62X-rite GmbH- Optotronik. The CIELAB system was used. In the CIELAB system, the $L^{*}$ axis represented the brightness ( $L^{*}$ varied from 100 (white) to zero (black)), and $a^{*}$ and $b^{*}$ were the chromaticity coordinates. ( $+a^{*}$ was for red, $a^{*}$ for green, $+b^{*}$ for yellow, $-b^{*}$ for blue). The obtained $L^{*}, a^{*}$ and $b^{*}$ values were used to calculate the colour changes $\Delta \mathrm{E}^{*}$ according to $\mathrm{Eq} 1$ (ISO /DIS 7724-3:1997):

$$
\Delta E^{*}=\sqrt{\left(\Delta L^{*}\right)^{2}+\left(\Delta a^{*}\right)^{2}+\left(\Delta b^{*}\right)^{2}}
$$

Where $\Delta L^{*}, \Delta a^{*}$ and $\Delta b^{*}$ were the differences between the colour values of the samples before and after the artificial ageing.

\subsection{Bond delamination}

2.4. Delaminacija lijepljenog spoja

Every 100 ageing cycles, the samples were weighed to measure water absorption, and checked for bond cracks. Crack lengths were measured on cross sections and photos were taken of delaminated bonds. The average length and sum of delaminations for all specimens with the same adhesive and heat treatment were calculated.

\subsection{Shear strength}

After ageing, we wanted to measure the influence of artificial ageing on the shear strength. The samples were cut into three $8 \mathrm{~mm}$ thick discs: outer disc - exposed to rain and UV/IR radiation, middle disc and rear disc. Each joint in each slice was loaded on a universal testing machine until failure, and shear strength and the percentage of wood failure were determined. For each adhesive and thermal treatment, 7 samples with two adhesive bonds (Figure 1 left) were tested - thus 14 adhesive bonds $(40 \mathrm{~mm} \times 8 \mathrm{~mm})$ and in total (separated slices for outer, middle and back slice) 252 bonds were tested. Average values were calculated as the average in each slice and the average in the whole sample (disregarding the position in the samples).

\section{RESULTS AND DISCUSSION}

\section{REZULTATI I RASPRAVA}

During the artificial ageing cycle, the samples were exposed to UV and IR radiation. The first visual change was the fading of the colour. The colour change shows severity of the ageing process (Kržišnik et al., 2018) and may also indicate some changes in surface structure and degradation, which could also be associated with the degradation of the adhesive bond. The surfaces of the samples turn grey and there were fewer colour differences between the control and most modified samples after ageing. The control samples became grey (decrease in L-value) and most modified samples (HT210, HT230) became lighter (increase in L-value) (Table1).

The colour change $\Delta E^{*}$ shows that the highest colour change occurred in the control samples, followed by the most heat treated samples - these were the 
Table 1 Surface colour before and after ageing process, CIELAB system

Tablica 1. Boje površine prije i nakon starenja, CIELAB sustav

\begin{tabular}{|c|c|c|c|c|c|c|c|}
\hline \multirow{2}{*}{$\begin{array}{c}\text { Sample } \\
\text { Uzorak }\end{array}$} & \multicolumn{3}{|c|}{ Before ageing / Prije starenja } & \multicolumn{3}{c|}{ After ageing / Nakon starenja } & \multirow{2}{*}{$\Delta E^{*}$} \\
\cline { 2 - 7 } & $L^{*}$ & $a^{*}$ & $b^{*}$ & $L^{*}$ & $a^{*}$ & $b^{*}$ & 1.48 \\
\hline Control & 82.90 & 3.88 & 22.43 & 67.87 & 7.50 & 22.96 & 13.41 \\
\hline HT150 & 81.08 & 5.14 & 25.35 & 68.30 & 6.50 & 21.54 & 12.01 \\
\hline HT 170 & 77.67 & 6.04 & 26.25 & 66.75 & 6.82 & 21.32 & 10.18 \\
\hline HT 190 & 67.12 & 9.91 & 29.05 & 60.75 & 6.68 & 21.79 & 11.94 \\
\hline HT 210 & 48.63 & 11.92 & 25.00 & 54.82 & 6.24 & 16.51 & 14.38 \\
\hline HT 230 & 40.79 & 11.70 & 22.31 & 52.62 & 6.41 & 16.06 & \\
\hline
\end{tabular}

Table 2 Weight increase (\%) in samples during ageing process. Values for standard deviation in brackets

Tablica 2. Povećanje mase (\%) uzoraka tijekom starenja; u zagradama su vrijednosti standardne devijacije

\begin{tabular}{|c|c|c|c|c|c|c|}
\hline \multirow{4}{*}{$\begin{array}{c}\text { Group of } \\
\text { samples }\end{array}$} & $\begin{array}{l}\text { Sample } \\
\text { Uzorak }\end{array}$ & \multicolumn{5}{|c|}{ Number of ageing cycles / Broj ciklusa izlaganja } \\
\cline { 2 - 7 } & Control & 100 & 200 & 300 & 400 & 500 \\
\cline { 2 - 7 } \begin{tabular}{c} 
Grupa uzoraka \\
\cline { 2 - 6 }
\end{tabular} & HT 150 & $15.7(1.1)$ & $18.1(1.8)$ & $16.1(1.9)$ & $15.8(2.4)$ & $18.9(2.5)$ \\
\cline { 2 - 7 } & HT170 & $14.1(4.7)$ & $19(2.0)$ & $17.6(2.7)$ & $19.5(3.2)$ & $21.1(4.5)$ \\
\cline { 2 - 7 } & HT190 & $10.3(2.4)$ & $12.5(1.9)$ & $12.8(6.7)$ & $18.1(6.9)$ & $19.3(6.1)$ \\
\cline { 2 - 7 } & HT210 & $8.9(1.0)$ & $12.1(1.6)$ & $10.8(2.3)$ & $13.7(3.1)$ & $13.9(2.2)$ \\
\cline { 2 - 7 } & HT230 & $6.2(1.0)$ & $7(1.2)$ & $9.2(5.1)$ & $8.5(1.8)$ & $8.8(2.0)$ \\
\hline
\end{tabular}

samples that initially showed the greatest difference with the control samples being the lightest and the most modified samples being the darkest (Table 2). The least colour change was seen in HT190. If the effect of the combination of wetting, UV and IR light was so intense that the colour of the surface was changed, this could also affect the bonds that were exposed to this treatment (Blanchet et al., 2003; Follrich et al., 2011), especially affecting the formation of bond cracks on exposed surfaces.

During the ageing process, the weight of the samples increased due to water absorption. The highest water absorption after 500 weathering cycles was measured in the case of control and less heat treated samples (HT150, HT170) and was $18.9 \%$ to $21.1 \%$ ) and decreased with increasing heat treatment temperature and was lowest for most heat treated woods (HT 2308.8 $\%)$. Statistical analysis showed only difference between control/less treated wood (HT150, HT 170) and more treated wood (HT190, HT210, HT230) groups. Higher water absorption also means higher swelling and stresses in glued joints, which could contribute to reducing bond shear strength with artificial ageing. Also, initial bond strength was determined on samples conditioned in standard climate (thus having $M C$ between $4.8 \%$-HT230 to $10.9 \%$ - control samples (Kariz, 2011), but the strength after ageing was measured on wet samples as the came from last ageing cycle. This higher $M C$ also affects the measured bond strength (Bomba et al., 2014).

\subsection{Bond delamination}

3.1. Delaminacija lijepljenog spoja

The PVAc adhesive bonds of HT210 and HT230 began to delaminate during the first 100 ageing cycles and the average crack length increased with the number of ageing cycles (Table 3 ). The delamination was highest on the most treated woods and the average de-

Table 3 Average delamination length and sum of delaminations (in brackets) in specimens with same adhesive and heat treatment after each 100 ageing cycles $(\mathrm{mm})$

Tablica 3. Srednja dužina delaminacije i ukupna delaminacija (u zagradama) na uzorcima s istim ljepilom i toplinskom modifikacijom nakon svakih 100 ciklusa starenja (mm)

\begin{tabular}{|c|c|c|c|c|c|c|c|c|c|c|c|}
\hline \multirow{9}{*}{$\begin{array}{c} \\
\text { Group of } \\
\text { samples } \\
\text { Grupa } \\
\text { uzoraka }\end{array}$} & \multirow{3}{*}{$\begin{array}{l}\text { Sample } \\
\text { Uzorak }\end{array}$} & \multicolumn{10}{|c|}{ Number of ageing cycles / Broj ciklusa izlaganja } \\
\hline & & \multicolumn{5}{|c|}{ PVAc } & \multicolumn{5}{|c|}{ MUF } \\
\hline & & 100 & 200 & 300 & 400 & 500 & 100 & 200 & 300 & 400 & 500 \\
\hline & Control & $\begin{array}{l}0.0 \\
(0)\end{array}$ & $\begin{array}{l}0.0 \\
(0)\end{array}$ & $\begin{array}{l}0.0 \\
(0)\end{array}$ & $\begin{array}{l}0.0 \\
(0)\end{array}$ & $\begin{array}{l}0.0 \\
(0)\end{array}$ & $\begin{array}{l}0.0 \\
(0)\end{array}$ & $\begin{array}{l}0.0 \\
(0)\end{array}$ & $\begin{array}{l}0.0 \\
(0)\end{array}$ & $\begin{array}{l}0.0 \\
(0)\end{array}$ & $\begin{array}{l}0.0 \\
(0)\end{array}$ \\
\hline & HT150 & $\begin{array}{l}0.0 \\
(0)\end{array}$ & $\begin{array}{c}0.1 \\
(1.4)\end{array}$ & $\begin{array}{c}0.3 \\
(5.5)\end{array}$ & $\begin{array}{c}0.5 \\
(7.6)\end{array}$ & $\begin{array}{c}0.7 \\
(11.1)\end{array}$ & $\begin{array}{l}0.0 \\
(0)\end{array}$ & $\begin{array}{l}0.0 \\
(0)\end{array}$ & $\begin{array}{l}0.0 \\
(0)\end{array}$ & $\begin{array}{l}0.0 \\
(0)\end{array}$ & $\begin{array}{l}0.0 \\
(0)\end{array}$ \\
\hline & HT170 & $\begin{array}{l}0.0 \\
(0)\end{array}$ & $\begin{array}{l}0.0 \\
(0)\end{array}$ & $\begin{array}{c}0.4 \\
(0.4) \\
\end{array}$ & $\begin{array}{c}0.6 \\
(8.0) \\
\end{array}$ & $\begin{array}{c}0.6 \\
(8.7) \\
\end{array}$ & $\begin{array}{l}0.0 \\
(0)\end{array}$ & $\begin{array}{l}0.0 \\
(0)\end{array}$ & $\begin{array}{l}0.0 \\
(0)\end{array}$ & $\begin{array}{l}0.0 \\
(0)\end{array}$ & $\begin{array}{l}0.0 \\
(0)\end{array}$ \\
\hline & HT190 & $\begin{array}{l}0.0 \\
(0)\end{array}$ & $\begin{array}{l}0.0 \\
(0)\end{array}$ & $\begin{array}{l}0.0 \\
(0)\end{array}$ & $\begin{array}{c}0.1 \\
(1.4)\end{array}$ & $\begin{array}{c}0.2 \\
(2.5)\end{array}$ & $\begin{array}{l}0.0 \\
(0)\end{array}$ & $\begin{array}{l}0.0 \\
(0)\end{array}$ & $\begin{array}{c}0.2 \\
(2.8)\end{array}$ & $\begin{array}{c}0.2 \\
(3.4)\end{array}$ & $\begin{array}{c}0.4 \\
(7.1)\end{array}$ \\
\hline & HT210 & $\begin{array}{c}3.1 \\
(36.6)\end{array}$ & $\begin{array}{c}4.1 \\
(49.1)\end{array}$ & $\begin{array}{c}4.8 \\
(57.6)\end{array}$ & $\begin{array}{c}5.5 \\
(65.5)\end{array}$ & $\begin{array}{c}5.6 \\
(66.7)\end{array}$ & $\begin{array}{l}0.0 \\
(0)\end{array}$ & $\begin{array}{l}0.0 \\
(0)\end{array}$ & $\begin{array}{c}1.4 \\
(22.1)\end{array}$ & $\begin{array}{c}2.1 \\
(33.2)\end{array}$ & $\begin{array}{c}2.3 \\
(37.3)\end{array}$ \\
\hline & HT230 & $\begin{array}{c}1.4 \\
(22.1)\end{array}$ & $\begin{array}{c}2.5 \\
(39.2)\end{array}$ & $\begin{array}{c}3.4 \\
(53.9)\end{array}$ & $\begin{array}{c}3.5 \\
(56.1)\end{array}$ & $\begin{array}{c}4.3 \\
(69.2)\end{array}$ & $\begin{array}{l}0.0 \\
(0)\end{array}$ & $\begin{array}{l}0.0 \\
(0)\end{array}$ & $\begin{array}{c}0.6 \\
(9.2)\end{array}$ & $\begin{array}{c}0.9 \\
(13.9)\end{array}$ & $\begin{array}{c}1.5 \\
(24.6) \\
\end{array}$ \\
\hline
\end{tabular}


lamination crack length was $5.6 \mathrm{~mm}$ for HT210 and 4.3 mm for HT230 after 500 cycles. The samples of less heat treated wood (HT150, HT170, HT190) showed only slight delamination with an average crack length less than $0.8 \mathrm{~mm}$. The bonds of control samples (nonmodified wood) did not show any cracks.

The delamination of MUF adhesive bonds started later than that of PVAc bonds, after 200 ageing cycles, and it was much lower. The highest delamination was also found at HT210, and the average crack length was $2.3 \mathrm{~mm}$ after 500 ageing cycles. Some delamination was also observed on HT230 (max. average crack length $1.6 \mathrm{~mm}$ ) and HT190 (max. average crack length less than $0.4 \mathrm{~mm})$. Other samples glued from less heat treated wood (HT150, HT170) and control samples showed no delamination.

One of the reasons for poorer performance of the PVAc adhesive could also be caused by the combined effect of increased water content and temperature. The PVAc adhesive is thermoplastic and softens at higher temperatures. During exposure, the samples on the IR radiation surface heat up to simulate solar radiation. The IR radiation lamps were adjusted so that the surface of the control samples reached a maximum of $60^{\circ} \mathrm{C}$. As the samples from heat-treated spruce had a darker colour, they heated up more and so the maximum temperature on the surface of most heat-treated samples (HT230) was up to $72^{\circ} \mathrm{C}$. This higher temperature on more treated samples could be one of the reasons for worse results in case of PVAc adhesive joints. PVAc adhesives have a low temperature resistance and soften above $50{ }^{\circ} \mathrm{C}$. A lower cohesive strength of the adhesive leads to delamination of the joint due to stresses acting on the joints as the wood, which is alternately exposed to drying and wetting, shrinks and swells.
Delamination increased for both adhesives with the degree of heat treatment (except HT230 and HT210) (Kariz et al., 2012) and the number of ageing cycles. The comparison between PVAc and MUF adhesive bonds showed that delamination was higher for PVAc adhesives than for MUF adhesives. The reason for this could be the properties of the adhesive - PVAc is thermoplastic and softens above $50{ }^{\circ} \mathrm{C}$. So, heating the surface of IR softens the adhesive and stresses due to swelling and shrinkage could cause the joints to open. The modified wood with darker surface colour (higher $L^{*}$ colour value) heated more than lighter control wood and this could increase the bond delamination of the modified wood.

\subsection{Shear strength}

\subsection{Smična čvrstoća}

The average shear strength of PVAc adhesive bonds decreased in all sample groups except HT230 with artificial ageing. The decrease was between $4.6 \%$ (HT190) and $8 \%$ (control samples). The average shear strength of HT230 increased by $20.1 \%$. Lower strength of aged joints is expected since stresses during exposure to heat and water decrease bond strength (Bengtsson et al., 2003, Zhao et al., 2011, Todaro et al., 2015).

The average shear strength of the first slice (the first $8 \mathrm{~mm}$ of samples) exposed to artificial weathering was lower than the strength of the rest of the adhesive bond. The biggest difference in the case of HT210 is due to the largest cracks in the bond lines. This was to be expected due to cracks occurring in the bond line exposed to swelling and shrinkage. However, high standard deviations show high variability of measurements (Figure 2). The statistical analysis of measurements of aged samples showed that there was no significant dif-

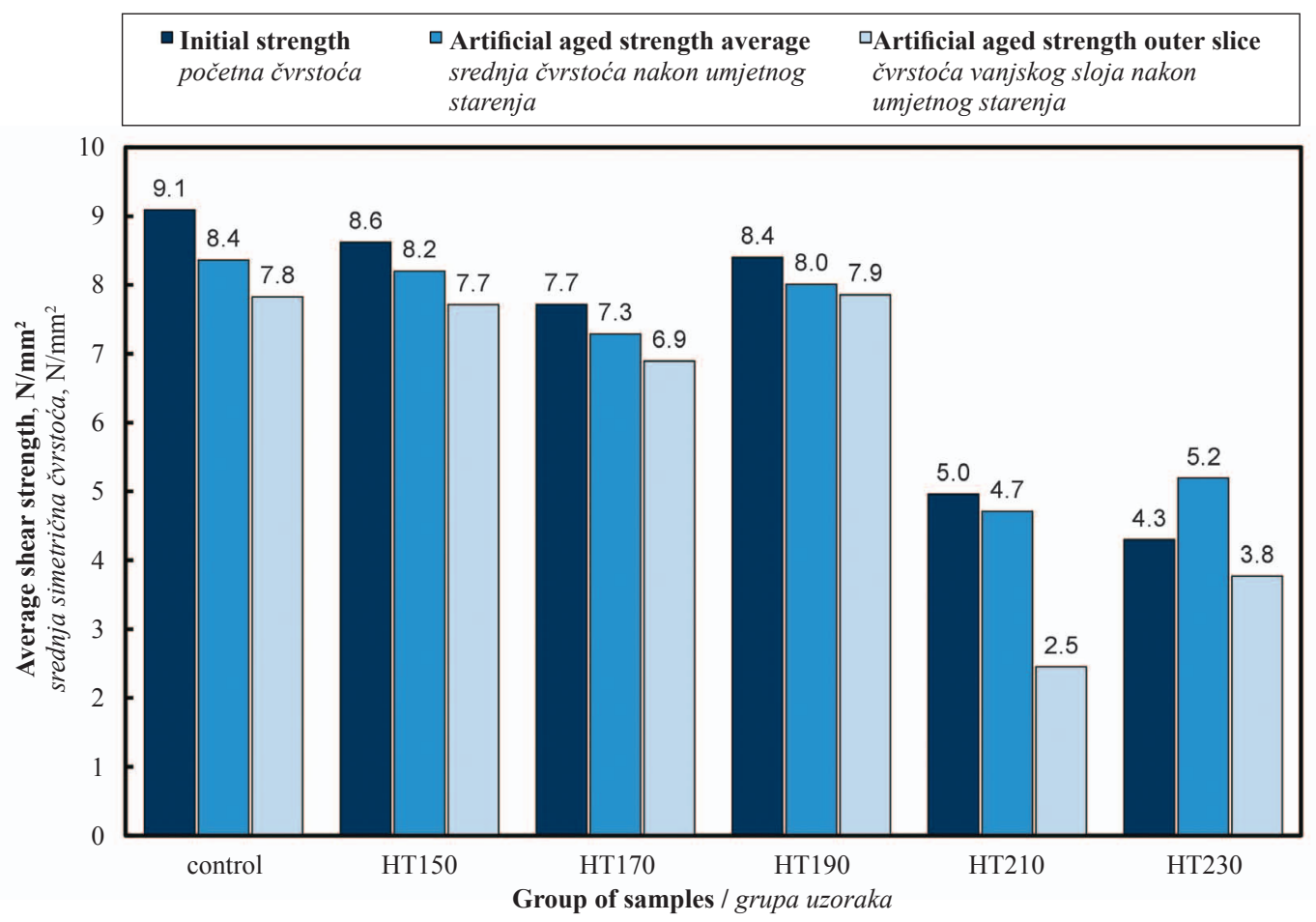

Figure 2 Average shear strength of PVAc bonds before and after artificial ageing

Slika 2. Srednja smična čvrstoća PVAc-om lijepljenog spoja prije i nakon umjetnog starenja 


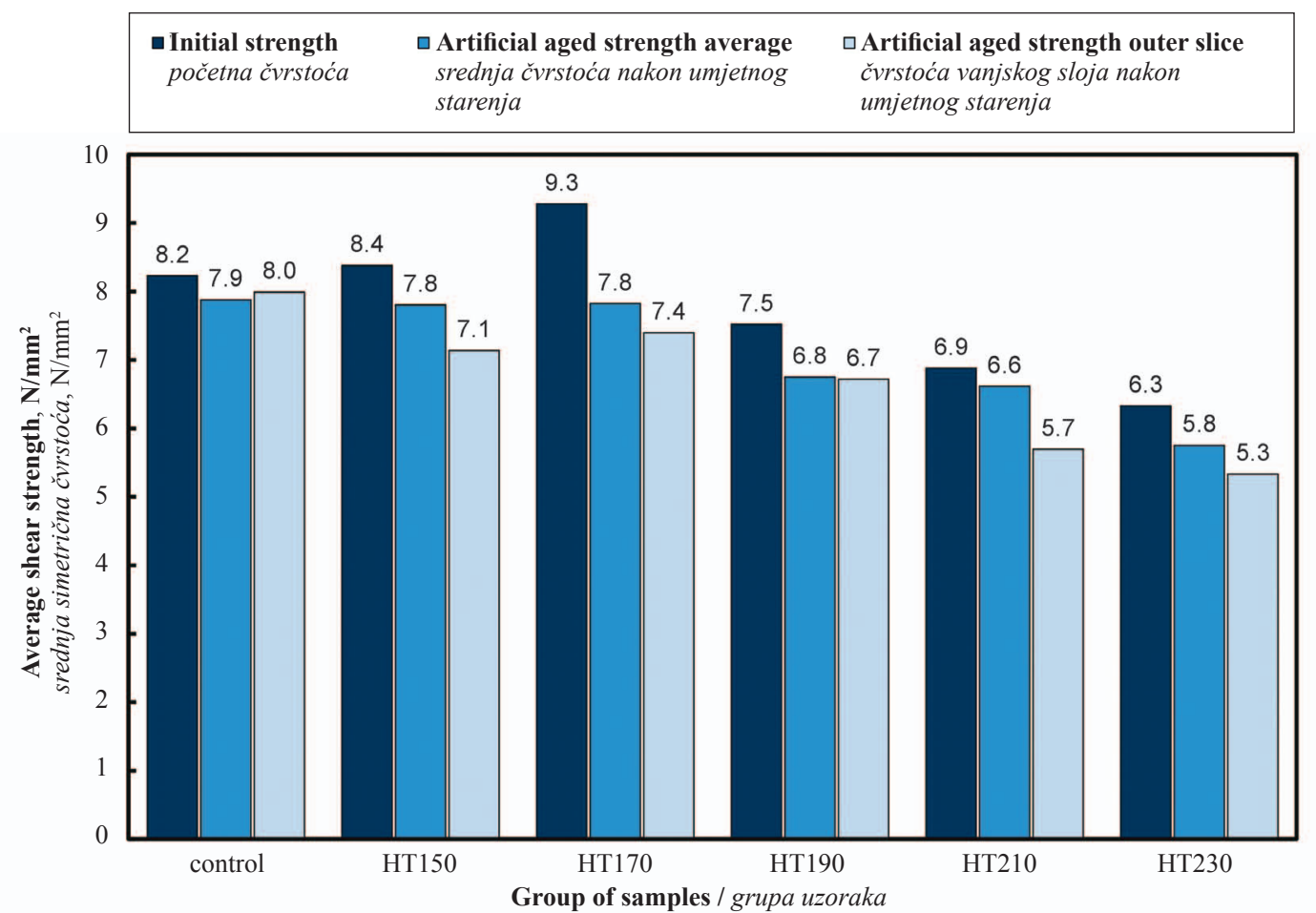

Figure 3 Average shear strength of MUF bonds before and after artificial ageing

Slika 3. Srednja smična čvrstoća MUF-om lijepljenog spoja prije i nakon umjetnog starenja

ference between average strengths between three measured layers (outer slice, middle slice, inner slice). The only exceptions were HT210 samples, where significant difference in strength between the outer and middle slice was observed. Statistical analysis for comparison of strength between the first outer slice and the average strength of the sample only showed significant difference in group HT210 and HT 230.

The average shear strength of MUF adhesive bonds decreased during artificial ageing for all groups of samples (Figure 3). The decrease was between 3.8 $\%$ (HT210) and $15.7 \%$ (HT170). The average shear strength of the first slice (exposed to artificial weathering) was lower than the average strength of the rest of the sample (except for the control samples). Statistical analysis showed high variability and significant difference in strength only for HT150 (difference in strength between the outer and inner layer) and HT210 (difference in strength between the outer and middle layer). Statistical analysis for comparison of strength between the first outer slice and the average strength of the sample only showed significant difference in group HT210.

The shear strength of adhesive bonds decreased with artificial ageing (except for PVAc HT230). This decrease was expected, but the actual decrease depends on the type of adhesive used, type of joint and ageing conditions (Follrich et al., 2011). The causes of degradation of bond lines can be divided into three categories: environment (climate, temperature, light, fungi, etc.), materials (type of adhesive, wood) and stresses (static loading, stresses from swelling and shrinking) (Gustódio et al., 2009), and all can affect the adherend (wood), adhesive or adhesive joint. Since natural ageing and weathering of joints take a long time and are strongly influenced by the macro- and microclimate, several artificial weathering testing procedures are used, making it hard to compare their findings (Follrich et al., 2011).

The average percentage of wood failure for MUF adhesive bonds was high and remained high after ageing (Table 4). The selected MUF adhesive is intended for structural joints in glulam, thus a high percentage of wood failure was expected. The average percentage of wood failure for bonds with PVAc adhesive decreased with the temperature of wood thermal modification. Artificially aged samples from the outer layer, made of more severely treated wood (HT210 and HT230), exhibit smaller decrease in wood failure.

\section{CONCLUSIONS}

\section{ZAKLJUČAK}

Artificial ageing changed the colour of the exposed surface of wood samples. During ageing cycles, cracks appear in the bond lines and their size increases with the duration of ageing. The time before the bond begins to delaminate depends on the type of adhesive and the degree of thermal modification of wood. In the case of PVAc adhesive, delamination occurred faster than with MUF adhesive. PVAc adhesive is thermoplastic and is softened by temperature, but MUF adhesive has higher temperature and water resistance and this could contribute to better results. The samples from thermally treated wood also started to delaminate before the samples made of untreated wood. Thermally treated wood has a darker colour so that it warmed up during light exposure to higher temperatures than control wood. Higher temperatures on the surface affect 
Table 4 Average percentage of wood failure (initial, average after ageing, average after ageing- for outer slice), standard deviations in brackets.

Tablica 4. Srednji postotak loma po drvu (početnog, srednjeg nakon starenja, srednjeg nakon starenja - vanjski sloj); u zagradama su standardne devijacije

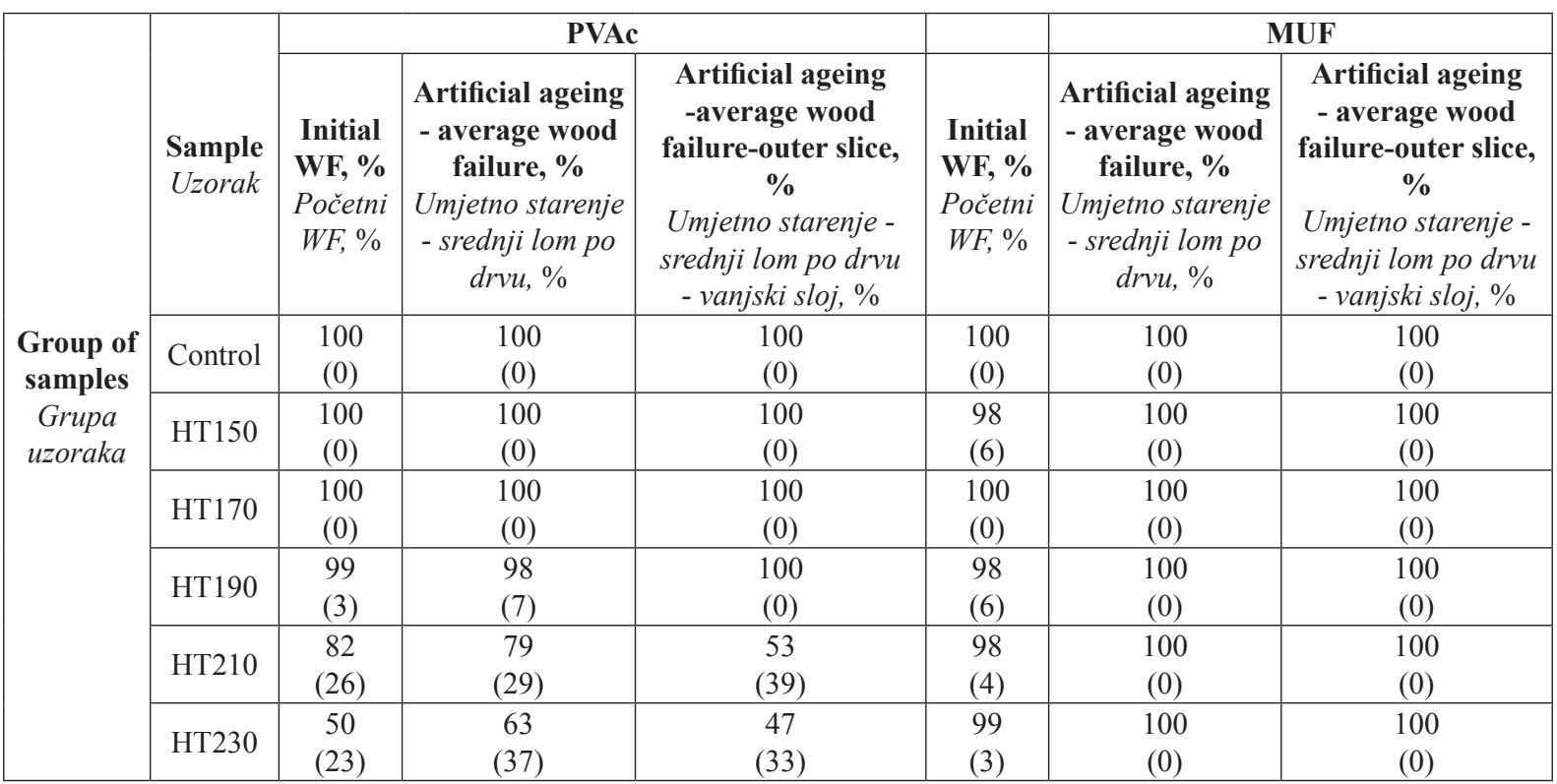

the adhesive, but also mean more drying and shrinking of wood, followed by water shower and cooling and swelling of wood, thus creating stresses on the surface and bonds.

The average shear strength of the joints decreased with increasing the number of ageing cycles (except PVAc HT230), and a small difference in strength between the outer layer and the average of the whole sample was noticed. However, the variability of the results is high and there is no statistically significant difference. Lower measured bond strengths are probably due to several factors: lower strength of heat treated wood, higher MC during testing of aged samples and bond cracks induced by the ageing process.

\section{Acknowledgements - Zahvala}

The authors acknowledge the support of the Slovenian Research Agency (ARRS) within the framework of research program P4-0015.

\section{REFERENCES}

\section{LITERATURA}

1. Blanchet, P.; Beauregard, R.; Erb, A.; Lefebvre, M., 2003: Comparative study of four adhesives used as binder in engineered wood parquet flooring. Forest Products Journal, 53 (1): 89-93.

2. Bengtsson, C.; Jermer, J.; Clang, A., 2003: Glulam of heat-treated wood-delamination test. In: Proceedings of The First European Conference on Wood Modification. Ghent, Belgium.

3. Bomba, J.; Šedivka, P.; Böhm, M.; Devera, M., 2014: Influence of moisture content on the bond strength and water resistance of bonded wood joints. BioResources, 9 (3): $5208-5218$.

https://doi.org/10.15376/biores.9.3.5208-5218.

4. Custódio, J.; Broughton, J.; Cruz, H., 2009: A review of factors influencing the durability of structural bonded timber joints. International Journal of Adhesion and Adhesives, 29 (2): 173-185.

doi.org/10.1016/j.ijadhadh.2008.03.002.

5. Esteves, B.; Pereira, H., 2009: Wood modification by heat treatment: A review. BioResources, 4 (1): 370-404. https://doi.org/10.15376/biores.4.1.370-404.

6. Follrich, J.; Teischinger, A.; Müller, U., 2011: Artificial ageing of softwood joints and its effect on internal bond strength with special consideration of flat-to-end grain joints. European Journal of Wood and Wood Products, 69 (4): 597-604.

https://doi.org/10.1007/s00107-010-0511-1.

7. Green, D. W.; Winandy, J. E.; Kretschmann, D. E., 1999: Mechanical properties of wood. In: Wood handbook wood as an engineering material. USDA Forest Products Laboratory, Madison, Chap 4.

8. Kariz, M., 2011: Vpliv termične modifikacije lesa na utrjevanje lepil in kakovost lepilnih slojev. PhD Thesis, University of Ljubljana, Ljubljana.

9. Kariz, M.; Kitek Kuzman, M.; Sernek, M., 2013: The effect of the heat treatment of spruce wood on the curing of melamine-urea-formaldehyde and polyurethane adhesives. Journal of Ahesion Science and Technology, 27 (17): 1911-1920. https://doi.org/10.1080/01694243.2013.764809.

10. Kariz, M.; Sernek, M., 2012: Bonding of heat-treated spruce with PVAc, PU and MUF adhesives. In: Proceedings of The Sixth European Conference on Wood Modification. Ljubljana, Slovenia, p.p. 247-250.

11. Kojima, Y.; Suzuki, S., 2011: Evaluating the durability of wood-based panels using internal bond strength results from accelerated ageing treatments. Journal of Wood Science, 57: 7-13.

https://doi.org/10.1007/s10086-010-1131-4.

12. Kržišnik, D.; Lesar, B.; Thaler, N.; Humar, M., 2018: Influence of natural and artificial weathering on the colour change of different wood and wood-based materials. Forests, 9 (8): 488. https://doi.org/10.3390/f9080488.

13. Marra, A. A., 1992: Technology of wood bonding - principles in practice. Van Nostrand - Reinhold, New York. 
14. Mayes, D.; Oksanen, O., 2003: ThermoWood Handbook. Finnish ThermoWood Association, Helsinki, Finland.

15. Militz, H., 2002: Thermal treatment of wood: European processes and their background. In: Proceedings of The International Research Group on Wood Preservation. Document No. IRG/WP 02-40241.

16. Rep, G.; Pohleven, F.; Bučar, B., 2004: Characteristics of thermally modified wood in vacuum. Report of The International Research Group on Wood Preservation. IRG/ WP 04-40287, p.p. 9.

17. Sernek, M.; Boonstra, M.; Pizzi, A.; Despres, A.; Gerardin, P., 2008: Bonding performance of heat treated wood with structural adhesives. Holz Roh Werkst, 66 (3): 173 180. https://doi.org/10.1007/s00107-007-0218-0.

18. Todaro, L.; Rita, A.; Moretti, N.; Cuccui, I.; Pellerano, A., 2015: Assessment of thermo-treated bonded wood performance: comparisons among Norway Spruce, Common Ash, and Turkey Oak. BioResources, 10 (1): 772 781. https://doi.org/10.15376/biores.10.1.772-781.
19. Vick, C. B., 1999: Adhesive bonding of wood materials. In: Wood Handbook - wood as an engineering material. USDA Forest Products Laboratory, Madison, Chapter 9.

20. Zhao, L.; Liu, Y.; Xu, Z.; Zhang, Y.; Zhao, F.; Zhang, S., 2011: State of research and trends in development of wood adhesives. Forest Studies China, 13 (4): 321-326. https://doi.org/10.1007/s11632-013-0401-9.

\section{Corresponding address:}

\section{MIRKO KARIZ}

University of Ljubljana

Biotechnical Faculty

Department of Wood Science and Technology Jamnikarjeva 101

1000 Ljubljana, SLOVENIA

e-mail: mirko.kariz@bf.uni-lj.si 